Dariusz Kubok

Uniwersytet Śląski, Katowice

ORCID: 0000-0003-3360-9667

e-mail: dariusz.kubok@us.edu.pl

\title{
Andrzeja Norasa kłopoty z filozofią i historią filozofii
}

Pandemia nie tylko drastycznie przerwała ciągłość znanego nam świata, ale przeniosła nas wszystkich do swoich ,jaskiń", zostawiając tylko wspomnienie wspólnego obcowania, normalnej rozmowy bez pośrednictwa kamer i mikrofonów, możliwości dotyku. W tym sensie przeżywany obecnie czas zdaje się czasem dziwnym, odrealnionym i przechodnim. Spodziewamy się, że to wszystko minie, a nawet jeśli nie wszystko, to przynajmniej powrócimy do $\mathrm{w}$ miarę normalnego funkcjonowania. Nie wiemy kiedy, ale mamy nadzieję, że niedługo spotkamy się w rzeczywistości akademickiej twarzą w twarz z koleżankami, kolegami i ze studentami. Wielu z nas chce zobaczyć w czasie zajęć grymas na twarzach swoich słuchaczy, ślady ich zainteresowania lub znudzenia i nie kierować słów do niewidzialnego odbiorcy. Powoli planujemy spotkania z przyjaciółmi z uczelni - wyjście na kawę, rozmowy, projekty. Przyłapuję się na tym, że wierzę, iż w ten sposób powróci to, co było przed pandemią. Nie wszystkich jednak spotkam na korytarzu Instytutu Filozofii w Katowicach. 4 grudnia 2020 roku zmarł Profesor Andrzej Noras (1960-2020).

Spotkania mogą przybierać różne formy, tak samo jak wspomnienia. Nie zetkniemy się z Profesorem Norasem ani na korytarzach uniwersyteckich, ani na trybunach stadionów piłkarskich, ani też na trasach rowerowych, ale nie ulega wątpliwości, że spotkamy się z nim wielokrotnie poprzez jego liczne publikacje: książki, artykuły i tłumaczenia. Wydaje mi się, że również w kwestii wspomnień dla Andrzeja Norasa najlepszą 
ich formą byłaby rozmowa z nim, z jego tekstami, z jego wizją filozofii i historii filozofii. Jeśli było coś, czego Noras nie znosił, to było to jedzenie drobiu i wyniosły patetyzm. Każdy polski filozof doskonale zna dorobek naukowy i translatorski Norasa, nie da się bowiem poważnie studiować filozofii współczesnej z pominięciem jego prac, a refleksja nad neokantyzmem bez znajomości jego dorobku jest po prostu niemożliwa. Zatem wspomnienie o Andrzeju Norasie może przybrać jedynie formę rozmowy z nim przez jego teksty. Rzetelnie wspominać kogoś to przecież podjąć rozmowę o czymś, co dla tego kogoś było ważne. Szczęśliwie się składa, że to, co było ważne dla Norasa, jest kluczowe dla filozofii w ogóle.

Niniejsze wspomnienie-rozmowa jest tylko $\mathrm{w}$ istocie zagajeniem, krótką wymianą zdań, taką jak przelotne, „,korytarzowe” rozmowy, które nam się przydarzają. W ich trakcie sygnalizowane są pewne zagadnienia, problemy, intuicje, a myśli nasycają się inspiracjami, odnajdują nowe obszary zainteresowań. Zapewne wkrótce powstaną dopracowane studia nad metafilozofią Norasa, jednak w tym miejscu, odwołując się do jego wybranych publikacji i licznych prywatnych dyskusji, warto wskazać pewne istotne kwestie.

Wydaje się, że tytuł tego wspomnienia-zagajenia - „Andrzeja Norasa kłopoty z filozofią i historią filozofii" - dobrze oddaje stosunek tego myśliciela do analizowanego problemu, ale może też być dla niektórych mylący. Według Słownika języka polskiego PWN „kłopot” to ",skomplikowana lub przykra sytuacja, wymagająca jakiegoś działania"1; według innego słownika z kolei jest to "trudna, skomplikowana lub przykra sytuacja, budząca niepokój, wymagająca jakiegoś działania"². Oczywiście nie chodzi o to, że Noras miał jakiś kłopot z filozofią i historią filozofii albo że stanowiły one dla niego przykrą sytuację; raczej trzeba powiedzieć, iż były dla niego czymś skomplikowanym, nieoczywistym, wymagającym trudu, a w każdym razie czymś, co skłania do jakiegoś działania. Filozof działa przez próbę zrozumienia, przez krytyczny namysł, godząc się jednak na to, że być może trudność ta nie zostanie zlikwidowana. Mimo to jednak działa, a jeśli wiąże się to z jakimś niepokojem, to dla Norasa był to przede wszystkim niepokój związany z deprecjacją historii filozofii i z jej niewłaściwym rozumieniem. Na zakończenie swojej książki Kłopoty z filozofia, której parafrazą tytułu jest tytuł niniejszego omówienia, pisze:

Dlatego też przesłanie wynikające $\mathrm{z}$ ukazanych w rozprawie problemów da się sprowadzić do konieczności odwołania się do historii filozofii. Nie ona jest problemem, lecz jej niewłaściwe rozumienie. Nie chodzi o histo-

1 https://sjp.pwn.pl/szukaj/k\%C5\%82opot.html, dostęp 31.05.2021.

${ }^{2}$ https://sjp.pl/k\%C5\%82opot, dostęp 31.05.2021. 
rię filozofii, która zdaje sprawę z życia i działalności tego czy tamtego myśliciela. Idzie tylko i aż o myślenie, które jest historyczne ${ }^{3}$.

To właśnie filozofia i jej historia stają się centralnymi zagadnieniami poszukiwań Norasa. Należałoby raczej powiedzieć, że jest to jedno zagadnienie, ponieważ nie da się tych dwu członów od siebie oddzielićt. Warto przyjrzeć się bliżej temu problemowi, traktując badania Norasa $\mathrm{w}$ tym zakresie jako pogłębione zagajenie problemu; warto z nim porozmawiać o tym, dzięki czemu wspomnienie ustąpi miejsca rozmowie, a to, co minione, temu, co aktualne, a być może zawsze aktualne. Będę się opierał na wybranych publikacjach autorskich Norasa ${ }^{5}$, ale także od-

${ }^{3}$ Andrzej J. Noras, Kłopoty z filozofia (Katowice: Wydawnictwo Uniwersytetu Śląskiego, 2015), 124.

${ }^{4}$ W artykule „Historia filozofii - nauka niepotrzebna?” Noras wyróżnia trzy stanowiska wyrażające relację między filozofią a jej historią: a) stanowisko stricte filozoficzne, w którym historia filozofii jest nauką podrzędną i pomocniczą b) stanowisko stricte historyczne zrównujące filozofię z historią filozofii, c) stanowisko historycznofilozoficzne godzace racje obu poprzednich. Pisze: „Tym samym w dyskusji filozofia versus historia filozofii jedynym możliwym stanowiskiem wydaje się stanowisko historycznofilozoficzne, ponieważ z rozmaitych powodów - które można uznać za założenia uprawiania filozofii bądź historii filozofii - łączy rozważania filozoficzne z rozważaniami dotyczącymi historii filozofii. Tak rozumiana filozofia (historia filozofii) byłaby jednością filozofii systematycznej i historii filozofii. Tę ostatnią jednak można by rozumieć jako historię problemów filozoficznych. I dopiero $\mathrm{w}$ takim kształcie mogłaby pretendować do miana filozofii, która nieustannie podejmuje problemy filozoficzne, bez gwarancji ich ostatecznego rozwiązania. Nazwa takiej filozofii stanowiłaby kwestię drugorzędną”. Andrzej J. Noras, „Historia filozofii nauka niepotrzebna?", w: Filozofia i czas przeszty: Profesorowi Czesławowi Głombikowi w 70. rocznice urodzin, red. Barbara Szotek (Katowice: Wydawnictwo Uniwersytetu Śląskiego, 2005), 108.

5 Przede wszystkim należy wymienić następujące teksty: Andrzej J. Noras, „Filozofia jako myślenie historyczne: spór o filozofię współczesną”, w: Przybliżanie przeszłości: księga pamiatkowa ofiarowana profesorowi Czesławowi Głombikowi z okazji czterdziestolecia pracy nauczycielskiej, red. Józef Bańka, przy współudziale Bogusława Szuberta (Katowice: Wydawnictwo Uniwersytetu Śląskiego, 1998), 112-120; Andrzej J. Noras, „O potrzebie filozofii systematycznej”, Przeglad Filozoficzny - Nowa Seria 4 (2000): 117-123; Andrzej J. Noras, „Filozofia a jej historia: próba charakterystyki”, w: Z problemów wspótczesnej humanistyki, red. Andrzej J. Noras (Katowice, 2003), 49-59; Andrzej J. Noras, „Co to znaczy »być krytycznym«?”, w: Prawda a metoda. Część I: Aporie myśli współczesnej, pod red. Janusza Jaskóły i Anny Olejarczyk (Wrocław: Wydawnictwo Uniwersytetu Wrocławskiego, 2003), 321-332; Andrzej J. Noras, „Historia filozofii - nauka niepotrzebna?", w: Filozofia i czas przeszły: Profesorowi Czesławowi Głombikowi w 70. rocznice urodzin, red. Barbara Szotek (Katowice: Wydawnictwo Uniwersytetu Śląskiego, 2005), 97-108; Andrzej J. Noras, „Nicolaia Hartmanna rozumienie filozofii", w: Między spekulacją a namysłem: ku źródłom badania filozoficznego, red. Andrzej Przyłębski (Poznań: WNS UAM, 2006), 81-93; Andrzej J. Noras, „Philosophiegeschichte als Problem der Marburger und Sudwestdeutschen Neukantianer", in: Marburg versus Sudwestdeutschland: Philosophische Differenzen zwischen den 
niosę się do niektórych jego przekładów ${ }^{6}$, których wybór jest oczywiście nieprzypadkowy, jako że wskazuje na teksty, które były dla niego ważne w tej dyskusji.

Źródłem problematyzowania tego zagadnienia są dla Norasa poglądy neokantystów, którzy stanowili dla niego obiekt ciągłego i pogłębionego zainteresowania ${ }^{7}$. W artykule Tezy do problemu historii filozofii przytacza on opinię Heinza Kimmerlego, w myśl której zagadnienie historii filozofii obejmuje trzy zagadnienia: a) wzajemny stosunek historii i filozofii, b) sposób odnoszenia się filozofii do swojej historii, c) relację historia-historia filozofiii ${ }^{8}$ W ten sposób historia filozofii może przybierać różne formy: doksografii, biografii, diadochografii czy też heresografii. Oczywiście kluczowym i wszechstronnie tematyzowanym problemem jest dla Norasa sposób odnoszenia się filozofii do swojej historii. Można chyba uznać to sformułowanie za leitmotiv jego dociekań metafilo-

beiden Hauptschulen des Neukantianismus, red. Christian Krijnen, Andrzej J. Noras (Wurzburg: Konigshausen \& Neumann, 2012), 115-139; Andrzej J. Noras, „Filozofia a jej dzieje: aktualność propozycji Nicolaia Hartmanna", w: Slovenske a pol'ske dialogy $v$ europskom filozofickom ramci, red. Zlatica Plašienková, Barbara Szotek (Bratislava: Stimul, 2012), 7-23; Andrzej J. Noras, „The debate on the method of philosophy at the turn of the 19th and the 20th centuries" Folia Philosophica 29 (2013): 15-61; Andrzej J. Noras, „Philosophy and its history: the validity of Nicolai Hartmann's proposal", in: Slovak and Polish reflections on historical and current philosophical issues, red. Zlatica Plašienková, Barbara Szotek (Bratislava: Comenius University, Faculty of Philosophy, 2013), 32-44; Andrzej J. Noras, „'Being Critical', Meaning What?”, w: Folia Philosophica 34 (2015), (Special issue: Forms of Criticism in Philosophy and Science, red. Dariusz Kubok (Katowice: Wydawnictwo Uniwersytetu Śląskiego, 2015), 61-76); Andrzej J. Noras, „Problem historii filozofii. Część pierwsza”, Ruch Filozoficzny 1 (2016): 7-27; Andrzej J. Noras, „Problem historii filozofii. Część druga”, Ruch Filozoficzny 2 (2016): 7-28; Andrzej J. Noras, „Das Problem der Philosophiegeschichte und die philosophische Bildung”, in: Philosophie und Bildung: Philosophie als Lehrerin kritischen Denkens, red. Iwona Alechnowicz-Skrzypek, Dorota Barcik, Hans Friesen (Freiburg: Verlag Karl Alber, 2017), 149-154; Andrzej J. Noras, „Tezy do problemu historii filozofii", Roczniki Filozoficzne 68 (2020): 5-32.

${ }^{6}$ Nicolai Hartmann, Wprowadzenie do filozofii. Autoryzowany zapis wykładu wygłoszonego w semestrze letnim 1949 roku w Getyndze, przeł. Andrzej J. Noras (Warszawa: Aletheia, 2000); Herbert Schnädelbach, „Opowiadać lub tworzyć historię?: jeszcze raz o sensie historii", przeł. Andrzej Kiepas, Andrzej J. Noras, w: Principia 34 (2003): 91-107; Ernst von Aster, "Jak studiuje się filozofię?", przeł. Andrzej J. Noras, Idea Studia nad struktura i rozwojem pojęć filozoficznych 20 (2008): 127-133; Wilhelm Windelband, „Historia filozofii”, przeł. Andrzej J. Noras, Idea - Studia nad struktura i rozwojem pojeć filozoficznych 22 (2010): 179-200; Eduard Zeller, „Historia filozofii, jej cele i drogi", przeł. Andrzej J. Noras, Idea - Studia nad struktura i rozwojem pojęć filozoficznych 23 (2011): 301-310.

7 Warto choćby wspomnieć o monumentalnej Historii neokantyzmu. Zob. Andrzej J. Noras, Historia neokantyzmu (Katowice, Wydawnictwo Uniwersytetu Śląskiego, 2012); w wersji niemieckiej: Andrzej J. Noras, Geschichte des Neukantianismus (Berlin: Peter Lang, 2020).

8 Andrzej J. Noras, „Tezy do problemu historii filozofii": 25. 
zoficznych. Stanowisko Norasa w tej kwestii jest zbieżne z ogólną ideą neokantyzmu: „Akcentowanie ścisłego związku między filozofią a jej historią można uznać za wyróżnik neokantyzmu" ${ }^{\prime \prime}$. Powstaje jednak pytanie o charakter tego związku i znaczenie „ścisłości”. Przede wszystkim należy zauważyć, że jest tu mowa o filozofii i jej historii, a nie po prostu o filozofii i historii filozofii. Noras wpisuje za Hartmannem to zagadnienie w projekt filozofii systematycznej, ale także w problem autorytetu.

Nicolai Hartmann - jak wiadomo - polemizował z tezą w myśl której zadaniem historyka filozofii jest zrozumienie tego, co myśleli inni dawni myśliciele; chodzi raczej o to, aby ponownie rozpoznać to, co oni poznali ${ }^{10}$. Nie potrafimy zrozumieć, co myśleli Parmenides, Platon czy Pyrron, nie idzie też o to, żeby skupiać się na ich biografii lub kontekstowej faktografii; kluczową sprawą jest rozumienie problemu, jego ponowne wyłuskanie i badanie. Jak wiadomo, kluczowy problem wiąże się z dyskusją dotyczącą tego, czy mamy do czynienia z tymi samymi problemami, z problemami odwiecznymi. Hans-Georg Gadamer żarliwie krytykował taki projekt neokantowski ${ }^{11}$. Nie wdając się w sedno tego sporu, warto zauważyć, że Gadamer przynajmniej stara się kierować dyskusję w stronę wrażliwego kontekstu problemów filozoficznych, nie tylko historycznych, ale także związanych z określonymi ramami teoretycznymi oglądu szczegółowych problemów. Noras dyskutuje z Gadamerowym poglądem, podkreślając różnicę pomiędzy tymi samymi a takimi samymi problemami. Problemy - te same problemy - powracaja, ale w nowych szatach. Znamienny jest tu przywołany przez Norasa cytat z Hartmanna: „To raczej same problemy mają historyczną ciągłość" ${ }^{\prime \prime}$. Należy dodać, że Hartmann myśli tu o treści problemów, które nie są akcydentalnym ludzkim wytworem, lecz przynależą niejako do świata. Według Hartmanna naszym zadaniem jest dostrzeżenie tych problemów. „Trzeba dopiero ponownego rozpoznania stałej zawartości problemu, by wniknąć głębiej. Trzeba mieć organ czuły na nie, trzeba

9 Tamże, 25.

10 Nicolai Hartmann, Myśl filozoficzna i jej historia, przeł. J. Garewicz, w: N. Hartmann, Myśl filozoficzna i jej historia. Systematyczna autoprezentacja (Toruń: Wydawnictwo Comer, 1994), 23.

11 „Również neokantowska historia problemu rościła sobie prawo do rozpoznawania w tych problemach własnych pytań, jednakże roszczenie ponadczasowych, »odwiecznych « problemów, aby powtarzały się one w coraz to nowych związkach systemowych, nie zostało dowiedzione i w rzeczywistości owe »identyczne« problemy zaczerpnięte zostały z pełną naiwnością z tworzywa filozofii idealistycznej i neokantowskiej”. Hans-Georg Gadamer, „Autobiografia”, przeł. J. Wilk, w: Gadameriana. Hans-Georg Gadamer w "Zbliżeniach Polska-Niemcy. Annäherungen Polen-Deutschland, red. Karol Bal, Jadwiga Wilk (Wrocław: Oficyna Wydawnicza ATUT, 2006), 25. Noras szczegółowo analizuje ten spór w artykułach „Problem historii filozofii. Część pierwsza”: 7-27 i „Problem historii filozofii. Część druga”: 7-28.

12 Nicolai Hartmann, „Myśl filozoficzna i jej historia”, 16. 
być samemu poszukiwaczem i badaczem, który w danym problemie tkwi, czyli trzeba być samemu myślicielem systematycznym"13. Trudno oprzeć się wrażeniu, że cytat ten oddaje credo naukowe Norasa. Poza tym jest to fragment, który zbliżał nas w dyskusjach: jego z przyczółków filozofii systematycznej, mnie - z perspektywy postawy zetetycznej.

Jednym z ulubionych obrazów Norasa - obok metafor sportowych był obraz Bernarda z Chartres opisującego badaczy jako karłów wspinających się na ramiona olbrzymów, aby widzieć dalej i więcej niż oni ${ }^{14}$. Noras postrzegał najnowsze dzieje jako kryzys autorytetu, nie tyle w sensie ich braku, lecz raczej ze względu na wykluczenie autorytetów. Warto zwrócić uwagę na motto jego książki Kłopoty z filozofią; przywołuje tam fragment z Cywilizacji spektaklu Maria Vargasa Llosy mówiący o tym, że społeczeństwo przestało się zajmować intelektualistami z powodu obniżenia rangi samego myślenia; w tym spektaklu nie gra ono już głównej roli. Jednak problem autorytetu jest istotny nie tylko ze względu na kondycję społeczeństwa, ale również w perspektywie filozoficznej. Powstaje pytanie, czy ramiona tych, a nie innych olbrzymów nie profilują partykularnego filozoficznego myślenia? Czy mój gigant nie odbiera mi wolności lub nie pogłębia stanowiskowości ${ }^{15}$ Noras słusznie zauważa, że ramiona danego olbrzyma siłą rzeczy determinują perspektywę oglądu świata. Trzeba jednak być tego po prostu świadomym. Zasadniczy problem bierze się jednak stąd, że określona perspektywa czy też stanowisko wyklucza inne perspektywy. Można powiedzieć, że jest to specyficzna forma zawłaszczania; widok (z ramion olbrzyma bądź z jakiejkolwiek innej pozycji) albo wyklucza inne widoki, albo ich nie dopuszcza, albo nie zdaje sobie sprawy $\mathrm{z}$ ich potencjalnego istnienia.

Krytykę tego zawłaszczenia wpisuje Noras w Hartmannową krytykę "-izmów" i w problem wolności badawczej. O ile przekonanie o niewykluczaniu się autorytetu i wolności nie jest nadmiernie kontrowersyjne, o tyle krytyka owych "-izmów” i stanowiskowości nastręcza sporo kłopotów. Sprawa nie byłaby tak niejasna, gdyby po prostu przyjąć - za Hartmannem - że system filozoficzny pokrywa się z konkretnym "-izmem". Wtedy konkluzja podejścia Hartmanna brzmi klarownie: system może być punktem dojścia, lecz nie powinien być punktem wyjścia ${ }^{16}$. Wydaje mi się jednak, że kwestia jest bardziej złożona. Po pierwsze wypracowanie określonych "-izmów" nie musi wiązać się z systemowym pojmowaniem filozofii; możliwa jest filozofia systematyczna operująca w ramach różnych „-izmów”. Po drugie w moim przekonaniu nie tyle

13 Tamże, 16.

14 Zob. np. Andrzej J. Noras, „Problem historii filozofii. Część pierwsza”: 8; Andrzej J. Noras, Kłopoty z filozofia, 48-49.

15 Tamże, 49.

16 Zob. tamże, 37. 
chodzi o krytykę „-izmów” jako takich, lecz o krytykę - jeśli można to tak nazwać - monoizmów. Sam Hartmann sprzeciw wobec „-izmów" traktował jako równoważny sprzeciwowi wobec ograniczania pola badawczego, szczególnie w punkcie wyjścia ${ }^{17}$; jest to de facto sprzeciw wobec redukcjonizmu, partykularyzmu i wykluczania odmienności perspektyw. Zdaje się, że systematyczna filozofia w wymiarze krytycznym powinna nie tylko nie ograniczać się do jednego typu oglądu innych perspektyw, lecz wręcz otworzyć się na inne perspektywy. Bliski mi jest w tym zakresie Odo Marquard, który twierdzi:

Niebezpieczny jest zawsze monomit, i co najmniej on; nie są natomiast niebezpieczne polimity. Trzeba mieć możność posiadania wielu mitów wielu historii; od tego wszystko zależy, kto - wespół z innymi ludźmi ma i mieć może tylko jeden mit - tylko jedną jedyną historię - ten źle na tym wychodzi. Stąd wniosek: strawna jest polimityczność, szkodliwa jest monomityczność. Kto polimitycznie - żyjąc i opowiadając - uczestniczy $\mathrm{w}$ wielu historiach, ten zawsze jednej historii zawdzięcza wolność od każdej innej et vice versa, co dotyczy także dalszych interferencji wielorako skrzyżowanych; kto monomitycznie - żyjąc i opowiadając - może i musi uczestniczyć tylko w jednej jedynej historii, ten nie ma tej wolności: jest całkowicie przez nią - by tak rzec, przez monomityczne zrównanie w uwikłaniu - bez reszty pochłonięty ${ }^{18}$.

Noras z kolei komentuje stanowisko Hartmanna w następujący sposób: „W istocie więc każdy »-izm《, jak chciał tego Hartmann, jest samowolnym (a często nawet mimowolnym) zawężeniem pola postrzegania problemu i dlatego skutkuje błędem"19. Tak więc - w moim przekonaniu - chodzi o przeciwstawienie się zarówno zawężaniu pola badania, jak i perspektywy samego oglądu oraz dopuszczenie innych perspektyw, innych opowieści. Warto podkreślić rysującą się postawę filozoficznej filoksenii związanej ściśle (a jakże!) z historycznofilozoficzną filoksenia; zespolone razem przeciwstawiają się egotycznym postawom negowania wszelkich obcobrzmiących metod myślenia filozoficznego. Ten aspekt wiąże się z zagadnieniem krytycyzmu, o którym jeszcze będzie mowa.

Zdaniem Norasa nie można w sposób rzetelny uprawiać filozofii bez znajomości historii filozofii; błędem jest sama alternatywa rozłączna: filozofia albo historia filozofii. Można by powiedzieć tylko pozornie paradoksalnie, że historia filozofii pozwala filozofii jednocześnie zakorzenić

17 Nicolai Hartmann, „Wprowadzenie do filozofii”. Autoryzowany zapis wykładu wygłoszonego w semestrze letnim 1949 roku w Getyndze, tłum. Andrzej J. Noras (Warszawa: Aletheia, 2000). Zob. Noras, „Co to znaczy »być krytycznym«?”: 329-330.

18 Odo Marquard, Rozstanie z filozofia pierwszych zasad. Studia filozoficzne, przeł. Krystyna Krzemieniowa (Warszawa: Oficyna Wydawnicza, 1994), 101-102.

${ }_{19}$ Andrzej J. Noras, Kłopoty z filozofia, 49-50. 
się w aktualności i wyzwolić się z pęt czasowości. Noras szczególnie żarliwie próbował uzasadnić konieczność odwołania się do historii filozofii w badaniach filozoficznych ${ }^{20}$, co zresztą jest specyfiką badań filozoficznych właśnie. Warto tu przypomnieć, że zagadnienie to niejako od drugiej strony starał się ukazać Stefan Swieżawski. Jego zadaniem stało się pokazanie, że historyk filozofii musi być filozofem. W rozprawie pod tytułem Etos historyka filozofii Stefan Swieżawski pisze, że

historyk filozofii jest zobowiązany do przestrzegania dwóch zasad: po pierwsze, winien się dobrze znać na problematyce filozoficznej, aby móc bezbłędnie określić przedmiot swoich badań i zastosować odpowiednie metody; po drugie, winien wiedzieć, w jaki sposób dziejopisarstwo filozoficzne służy samej filozofii i $\mathrm{w}$ jakiej mierze jest ono niezbędne dla prawdziwego doświadczenia filozoficznego ${ }^{21}$.

Wiele miejsca $\mathrm{w}$ swoich dociekaniach metafilozoficznych poświęcił Noras kwestii punktu wyjścia w dociekaniach. Zajął w duchu neokantowskim pozycję pomiędzy dwiema skrajnościami: stanowiskowością o charakterze dogmatycznym a bezzałożeniowością. O bezzałożeniowości sporo pisał i żarliwie uznawał tę ideę za fikcję, w czym nie był osamotniony; nie chodzi tylko o poglądy Hartmanna, ale w tym kontekście przywołuje Władysława Stróżewskiego, Jana Woleńskiego, Leszka Kołakowskiego czy ks. Józefa Herbuta. Jednym z ulubionych przez Norasa powiedzeń był cytat z Josefa Piepera przywołującego T.S. Eliota: „Osobliwość tak rozumianej filozofii »bezzałożeniowej« zwykła wówczas polegać właśnie na tym, że, jak powiada T.S. Eliot o »niektórych filozofach «, założenia są »W równym stopniu ukryte przed autorem, jak i przed czytelnikiem «"22. Natomiast kwestia stanowiskowości, szczególnie ujawniająca się $\mathrm{w}$ punkcie wyjścia, wiąże się z zagadnieniem krytycyzmu. Również w tym aspekcie użyteczne dla Norasa były poglądy Piepera.

20 „Tymczasem historia filozofii w żaden sposób nie jest związana z »etapem heurezy «, a raczej ujawnia się u podstaw filozoficznej pracy, tworząc fundament filozofii i punkt wyjścia zarazem. Historia filozofii nie jest dyscypliną naukową uprawianą obok filozofii - w znaczeniu podrzędności, bo przecież filozofia z definicji jest nadrzędna - lecz stanowi istotny czynnik filozofii samej”. Andrzej J. Noras, „Problem historii filozofii. Część pierwsza": 9.

${ }_{21}$ Stefan Swieżawski, „Etos historyka filozofii”, w: Stefan Świeżawski, Istnienie i tajemnica (Lublin: Redakcja Wydawnictw KUL, 1993), 249. O powinnościach filozoficznej historii filozofii w ujęciu Norasa zob. Andrzej J. Noras, „Problem historii filozofii. Część pierwsza": 22-23.

22 Josef Pieper, W obronie filozofii, tłum. Piotr Waszczenko (Warszawa: Instytut Wydawniczy PAX, 1985), 74. 
Warto przywołać dwa podobne fragmenty z książki $W$ obronie filozofii:

- „Być »krytycznym« to dla kogoś filozofującego nie znaczy w pierwszym rzędzie: dopuszczać do uznawania tylko tego, co absolutnie pewne; lecz: dbać o to, by niczego nie pominąćc ${ }^{23}$.

- „[...] być »krytycznym « oznacza dla kogoś filozofującego tyle, co: troszczyć się o to, by niczego nie pominąć'"24.

Noras przywoływał te fragmenty, aby podkreślić konieczność uwzględnienia każdego aspektu problemu i nie ograniczać się tylko do jednej perspektywy (nie popadać w monomityczną stanowiskowość). Tymczasem sam Pieper te dwie tezy łączy odpowiednio z 1) z krytyką priorytetowego uznawania wyłącznie pewności, i z 2) powinnością kierowania się w stronę całości rzeczywistości niepojętej jako suma części. Widać zatem, że Noras poszerza i w pewnym sensie przekracza stanowisko Piepera, bo - co sam często podkreślał, parafrazując wypowiedź Wilhelma Windelbanda o Kancie - zrozumieć kogoś oznacza wykroczyć poza niego ${ }^{25}$. Owa troska o to, by nie pomijać niczego, wiąże się przede wszystkim z krytycznym wymiarem filozofii. W ten sposób Noras czytał Piepera, a raczej postulat Piepera, bo wiele $z$ tez zawartych $w$ jego książce odczytywać można w duchu dogmatycznym. Noras komentuje drugi z przytoczonych fragmentów Piepera następująco: Filozofia „musi być antydogmatyczna w punkcie wyjścia, a troskę o metodę winna uznać wprawdzie za ważny, ale nie najważniejszy element refleksji"26. Przy okazji moich badań nad krytycyzmem i krytycystycznym rozumieniem filozofii prowadziłem ożywioną dyskusję z Norasem zarówno o istocie tej postawy, jak i o historii problemu. Był to problem, który go szczególnie zajmował, a przejawiało się to w równie żarliwej niechęci do dogmatyzmu, pychy i patetyzmu.

Rzecz jasna, mówiąc o krytycyzmie i filozofii krytycznej, nie należy ich utożsamiać wyłącznie ze stanowiskiem Kanta, choć jego wkładu $\mathrm{w}$ tematyzowanie tego zagadnienia nie da się pominąć. Problem relacji pomiędzy filozofią a krytycyzmem jest złożony ${ }^{27}$, warto choćby wy-

23 Tamże, 37

24 Tamże, 59.

25 „Windelband dostrzega więc konieczność uprawiania innego rodzaju filozofii (i historii filozofii zarazem). Skoro zrozumieć oznacza przekroczyć, to trudno mówić o tym, że historyk filozofii jest tym, który jedynie „zdaje sprawę". A skoro nie może „wykroczyć poza” i „przekroczyć kogoś” zupełnie dowolnie, to musi być tym, który wie, poza kogo wykracza. Innymi słowy - co w zasadzie zdaje się budzić zdziwienie tylko filozofów - historyk filozofii musi być filozofem”. Andrzej J. Noras, „Problem historii filozofii. Część pierwsza": 8.

${ }^{26}$ Noras, "Co to znaczy »być krytycznym«?", 329.

${ }^{27}$ Zob. na przykład Dariusz Kubok, "Critical thinking and philosophical criticism - an outline of the problem", in: Thinking Critically: What Does It Mean? The 
punktować te aspekty, które były dla Norasa szczególnie ważne. W wyróżnianych przeze mnie typach krytycyzmu fundamentalną i fundującą funkcję ma krytycyzm separacyjny. Noras zdawał się podzielać to przekonanie, szczególnie wtedy gdy pisał o krytycyzmie jako o ustalaniu granic $^{28}$. O wadze krytycyzmu w myśleniu nie warto chyba wspominać, wydaje się to oczywiste w myśleniu i kształceniu. Ale Noras nie byłby sobą gdyby nie związał krytycyzmu z historią filozofii: „Oczywiście, przyznanie historii filozofii należnego miejsca $\mathrm{w}$ ramach rozważań systematycznych stanowi istotny element krytycyzmu, chociaż nie jest to jedyny element wyznaczający jego istotę. Innymi słowy, historia filozofii stanowi bez wątpienia warunek dostateczny filozofii krytycznej"29. Poza tym (w duchu Kanta i Jaspersa) krytycyzm zostaje ujęty jako umiejętność rozpoznawania granic rozumu i antydogmatyzm. Nie ma tu miejsca, aby rozwijać te wątki, warto tylko powiedzieć, że filozoficzny krytycyzm w powiązaniu z refleksją historycznofilozoficzną manifestował się w przypadku Norasa połączeniem erudycji i pokory.

Traktuję niniejszy tekst nie jako pożegnanie lub wspomnienie, lecz jako zagajenie rozmowy z Andrzejem $\mathrm{w}$ nieco innej formie; ale jest to tylko wprowadzenie, zasygnalizowanie pewnych wątków ważnych dla niego, ale też dla mnie. Nagła nieobecność filozofa nie przeszkadza $\mathrm{w}$ rozmowie $\mathrm{z}$ nim, z jego poglądami, z jego sposobem widzenia rzeczy. I w tym sensie niewiele się zmienia. Śmierć filozofa czyni niemożliwą obserwację możliwej zmiany jego poglądów i fascynujących jej skutków dla dalszej dyskusji. Wielu z nas odczuwa ten brak.

\section{Bibliografia}

Aster Ernst von. 2008. „Jak studiuje się filozofię?”, przeł. Andrzej J. Noras, Idea - Studia nad struktura i rozwojem pojęć filozoficznych 20: 127-133.

Gadamer Hans-Georg. 2006. „Autobiografia”, przeł. J. Wilk. W: Gadameriana. Hans-Georg Gadamer w "Zblizeniach Polska-Niemcy. Annäherungen Polen-Deutschland, red. Karol Bal, Jadwiga Wilk. Wrocław: Oficyna Wydawnicza ATUT.

Hartmann Nicolai. 2000. Wprowadzenie do filozofii. Autoryzowany zapis wykładu wygłoszonego w semestrze letnim 1949 roku w Getyndze, przeł. Andrzej J. Noras. Warszawa: Aletheia.

Hartmann Nicolai. 2000. Wprowadzenie do filozofii. Autoryzowany zapis wykładu wygłoszonego w semestrze letnim 1949 roku w Getyndze, tłum. Andrzej J. Noras. Warszawa: Aletheia.

Tradition of Philosophical Criticism and Its Forms in the European History of Ideas, red. Dariusz Kubok (Berlin, Boston: De Gruyter, 2018), 1-10.

${ }_{28}$ Zob. Andrzej J. Noras, Kłopoty z filozofia, 50.

29 Tamże, 90. 
Kubok Dariusz. 2018. „Critical thinking and philosophical criticism - an outline of the problem". In: Thinking Critically: What Does It Mean? The Tradition of Philosophical Criticism and Its Forms in the European History of Ideas, red. Dariusz Kubok, 1-10. Berlin, Boston: De Gruyter.

Marquard Odo. 1994. Rozstanie z filozofia pierwszych zasad. Studia filozoficzne, przeł. Krystyna Krzemieniowa. Warszawa: Oficyna Wydawnicza.

Noras Andrzej J. 1998. „Filozofia jako myślenie historyczne: spór o filozofię współczesną". W: Przybliżanie przeszłości: księga pamiatkowa ofiarowana profesorowi Czesławowi Głombikowi z okazji czterdziestolecia pracy nauczycielskiej, red. Józef Bańka, przy współudziale Bogusława Szuberta, 112-120. Katowice: Wydawnictwo Uniwersytetu Śląskiego.

Noras Andrzej J. 2000. „O potrzebie filozofii systematycznej”, Przeglad Filozoficzny - Nowa Seria 4: 117-123.

Noras Andrzej J. 2003. „Co to znaczy »być krytycznym«?”. W: Prawda a metoda. Część I: Aporie myśli współczesnej, pod red. Janusza Jaskóły i Anny Olejarczyk, 321-332. Wrocław: Wydawnictwo Uniwersytetu Wrocławskiego.

Noras Andrzej J. 2003. „Filozofia a jej historia: próba charakterystyki”. W: Z problemów wspótczesnej humanistyki, red. Andrzej J. Noras, 49-59. Katowice.

Noras Andrzej J. 2005. „Historia filozofii - nauka niepotrzebna?”. W: Filozofia i czas przeszły: Profesorowi Czesławowi Głombikowi w 70. rocznicę urodzin, red. Barbara Szotek, 97-108. Katowice: Wydawnictwo Uniwersytetu Śląskiego.

Noras Andrzej J. 2005. „Historia filozofii - nauka niepotrzebna?”. W: Filozofia i czas przeszły: Profesorowi Czesławowi Głombikowi w 70. rocznice urodzin, red. Barbara Szotek, 97-108. Katowice: Wydawnictwo Uniwersytetu Śląskiego.

Noras Andrzej J. 2006. „Nicolaia Hartmanna rozumienie filozofii”. W: Między spekulacja a namysłem: ku źródłom badania filozoficznego, red. Andrzej Przyłębski, 81-93. Poznań: WNS UAM.

Noras Andrzej J. 2012. „Filozofia a jej dzieje: aktualność propozycji Nicolaia Hartmanna". In: Slovenske a pol'ske dialogy v europskom filozofickom ramci, red. Zlatica Plašienková, Barbara Szotek, 7-23. Bratislava: Stimul.

Noras Andrzej J. 2012. „Philosophiegeschichte als Problem der Marburger und Sudwestdeutschen Neukantianer". In: Marburg versus Sudwestdeutschland: Philosophische Differenzen zwischen den beiden Hauptschulen des Neukantianismus, red. Christian Krijnen, Andrzej J. Noras, 115-139. Wurzburg: Konigshausen \& Neumann.

Noras Andrzej J. 2012. Historia neokantyzmu. Katowice: Wydawnictwo Uniwersytetu Śląskiego.

Noras Andrzej J. 2013. „Philosophy and its history: the validity of Nicolai Hartmann's proposal". In: Slovak and Polish reflections on historical and current philosophical issues, red. Zlatica Plašienková, Barbara Szotek, 32-44. Bratislava: Comenius University, Faculty of Philosophy. 
Noras Andrzej J. 2013. „The debate on the method of philosophy at the turn of the 19th and the 20th centuries". Folia Philosophica 29: 15-61.

Noras Andrzej J. 2015. „'Being Critical', Meaning What?”. Folia Philosophica 34: 61-76 (Special issue: Forms of Criticism in Philosophy and Science, red. Dariusz Kubok, Katowice: Wydawnictwo Uniwersytetu Śląskiego).

Noras Andrzej J. 2015. Kłopoty z filozofia. Katowice: Wydawnictwo Uniwersytetu Śląskiego.

Noras Andrzej J. 2016. „Problem historii filozofii. Część druga”, Ruch Filozoficzny 2: 7-28.

Noras Andrzej J. 2016. „Problem historii filozofii. Część pierwsza”. Ruch Filozoficzny 1: 7-27.

Noras Andrzej J. 2017. „Das Problem der Philosophiegeschichte und die philosophische Bildung". In: Philosophie und Bildung: Philosophie als Lehrerin kritischen Denkens, red. Iwona Alechnowicz-Skrzypek, Dorota Barcik, Hans Friesen, 149-154. Freiburg: Verlag Karl Alber.

Noras Andrzej J. 2020. „Tezy do problemu historii filozofii”, Roczniki Filozoficzne 68: 5-32.

Noras Andrzej J. 2020. Geschichte des Neukantianismus. Berlin: Peter Lang.

Pieper Josef. W obronie filozofii, tłum. Piotr Waszczenko. Warszawa: Instytut Wydawniczy PAX.

Schnädelbach Herbert. 2003. „Opowiadać lub tworzyć historię?: jeszcze raz o sensie historii", przeł. Andrzej Kiepas, Andrzej J. Noras, Principia 34: 91-107.

Swieżawski Stafan. 1993. „Etos historyka filozofii”. W: Stefan Swieżawski: Istnienie i tajemnica. Lublin: Redakcja Wydawnictw KUL.

Windelband Wilhelm. 2010. „Historia filozofii”, przeł. Andrzej J. Noras, Idea - Studia nad struktura i rozwojem pojęć filozoficznych 22: 179-200.

Zeller Eduard. 2011. „Historia filozofii, jej cele i drogi”, przeł. Andrzej J. Noras, Idea - Studia nad struktura i rozwojem pojęć filozoficznych 23: 301-310. 